\title{
RANCANGAN SISTEM PENANGANAN MATERIAL UNTUK MEMINIMASI RISIKO GANGGUAN SISTEM TULANG DAN OTOT
}

\author{
Yanti Helianty ${ }^{1}$, Dinni Emalia ${ }^{2},{\text { Caecilia } \mathrm{Sw}^{3}}^{3}$ \\ Jurusan Teknik Industri, Institut Teknologi Nasional Bandung ${ }^{1,2,3)}$ \\ Jl. PH.H Musthofa No.23, Bandung, Jawa Barat, 40124 \\ Email:yanti@itenas.ac.id ${ }^{l}$
}

\begin{abstract}
Manual Material Handling process often caused a danger to the health and safety workers, such as accidents at work and injured muscle (musculoskeletal disorder) on the part of worker's body. In this study will suggest to improve the alternative of manual handling in Menjangan soy sauce factory. From di proposed result that the work force on segment of the worker's body smaller than the work force by using the old way. With a smaller force, the moment that occurs will be samller, so that the work load becomes lighter. With a lighter work load can minimize the possibility of a muscle injury in the works.
\end{abstract}

Keywords : Manual Material Handling, Musculoskeletal Disorder, Moment, Workload.

\section{PENDAHULUAN}

Pekerjaan penanganan material secara manual (Manual Material Handling) pada dekade belakangan ini merupakan sumber utama komplain karyawan di beberapa industri (Helianty Yanti, Mona Citra P, Caecilia Sw, 2012). Aktivitas manual material handling $(\mathrm{MMH})$ yang tidak tepat dapat menimbulkan kerugian bahkan kecelakaan pada karyawan. Akibat yang ditimbulkan dari aktivitas MMH yang tidak benar, salah satunya adalah keluhan muskoloskeletal. Keluhan muskoloskeletal adalah keluhan pada bagian-bagian otot skeletal yang dirasakan oleh seseorang mulai dari keluhan yang sangat ringan sampai sangat sakit. Apabila otot menerima beban statis secara berulang dalam jangka waktu yang lama akan dapat menyebabkan cidera berupa kerusakan pada sendi, ligamen dan tendon (Grandjean, Etienne, 1988).

Cidera ini yang biasanya disebut sebagai muskoloskeletal disorder (MSDs) atau cedera pada sistem muskuloskeletal. Tingginya tingkat cidera atau kecelakaan kerja selain merugikan secara langsung yaitu sakit yang di derita oleh pekerja, kecelakaan tersebut juga akan berdampak buruk terhadap kinerja perusahaan yaitu berupa penurunan produktivitas perusahaan, baik melalui beban biaya pengobatan yang cukup tinggi dan juga ketidakhadiran pekerja serta penurunan dalam kualitas kerja.

Penanganan material secara manual dapat berupa membawa, meletakkan, mengangkat, mendorong dan menarik beban. Beban yang dikerjakannyapun bermacam macam ada yang kecil, besar, ringan, berat, dengan atau tanpa pegangan. Dalam dunia industri penganganan material secara manual masih banyak dilakukan, misalnya membawa material dari gudang, mengangkat dan memindahkan material dari satu tempat ke tempat lain, memasukkan benda kedalam box, dan lain - lain.

Proses pengangkatan dan pemindahan secara manual seringkali menimbulkan potensi yang membahayakan keselamatan pekerja, seperti timbulnya kecelakaan ketika bekerja dan cedera pada bagian tubuh pekerja (musculoskeletal disorder) akibat beban kerja berlebih (Chaffin, Don B, and Gunnar, 1991). Cedera ini mungkin akan terasa akibatnya oleh pegawai setelah sekian lama bekerja ataupun saat pegawai berhenti dari pekerjaannya. Akumulasi dari gejala ini dapat menimbulkan cedera permanen pada pekerja yang akhirnya menyebabkan turunnya produktivitas kerja. Penelitian MMH yang sudah dilakukan lebih banyak pada kajian mengukur gaya dan moment pada tulang belakang L5-S1 seperti 
penelitian Mas'idah dkk mengenai analisis MMH untuk meminimasi resiko cidera pada tulang belakang pada proses pengangkatan barang di pabrik genteng. Penelitian Helianty, dkk. mengenai usulan rancangan alat bantu untuk meminimasi gaya tekan pada tulang belakang (L5-S1) pada proses pengangkatan beras, dan penelitianpenelitian lainnya yang memfokuskan pada analisis gaya tekan pada tulang belakang (L5-S1).

Sementara itu gangguan muskuloskeletal adalah gangguan pada sistem muskuloske-letal yaitu keluhan pada bagian-bagian otot skeletal (otot leher, bahu, lengan, tangan, jari, punggung, pinggang dan otot-otot bagian bawah) yang dirasakan oleh seseorang mulai dari keluhan sangat ringan

sampai sangat sakit disebabkan oleh aktivitas kerja. Sehingga dampak dari aktivitas, khususnya pada aktivitas $\mathrm{MMH}$ tidak hanya berdampak pada tulang belakang saja tetapi juga dapat berdampak juga pada otot dan persendian. Pada penelitian akan dilakukan analisis gaya yang terjadi pada setiap persendian tubuh pada saat melakukan aktivitas MMH. Penelitian ini lebih kepada pendekatan kuantitatif untuk menggambarkan besarnya gaya yang terjadi pada setiap segmen tubuh pekerja, bukan hanya pada tulang belakang L5-S1, pada saat melakukan aktivitas $\mathrm{MMH}$ sehingga semakin menyadarkan para pekerja tentang resiko MMH.

MMH lebih banyak dilakukan pada industri kecil. Hal ini disebabkan karena alat MH biasanya cukup mahal. Selain itu terkait kondisi industri kecil itu sediri dengan lokasi yang sangat terbatas atau sempit, sehingga tidak mudah dilakukan apabila menggunakan alat $\mathrm{MH}$.

Pada umumnya pemilihan jenis penanganan material (material handling) di industri hanya memperhatikan kapasitas dan kemudahan dalam pemakaiannya. Jarang sekali memperhatikan masalah keamanan, kenyamanan dan kesehatan bagi pekerjanya. Demikian juga halnya di pabrik kecap Maja Menjangan yang merupakan industri kecil yang bergerak dalam pembuatan kecap dalam kemasan botol, dimana pekerjaan pengangkatan dan pemindahan bahan baku dan hasil pengolahan masih dilakukan secara manual. Pengangkatan dan pemindahan barang dilakukan dengan cara dipikul dan menggunakan alat bantu berupa tongkat. Pekerjaan ini dilakukan rata - rata lebih dari 10 kali dalam satu hari.

Berdasarkan pengamatan awal bahwa adanya keluhan dari para pekerja pada beberapa bagian tubuh, serta berdasarkan analisis bahwa cara pengangkatan dan pemindahan yang dilakukan pada saat ini memiliki resiko yang sangat besar untuk terjadinya cedera otot. Untuk itu diperlukan perancangan suatu alat bantu pengangkatan dam pemindahan barang yang dapat meminimasi terjadinya resiko cedera otot pada saat bekerja.

\section{METODOLOGI PENELITIAN}

Metode penelitian yang dilakukan dalam penelitian diuraikan sebagai berikut :

\section{a. Identifikasi dan Analisis Cara Pengangkatan Barang pada Kondisi Awal}

Pada bagian ini terlebih dahulu dilakukan analisis terhadap kegiatan pengangkatan beban yang di lakukan selama ini. Hal ini penting sekaligus untuk mengidentifikasi cara dan posisi pengangkatan yang memberikan beban berlebih pada tulang belakang. Tekanan tekanan yang terjadi pada tulang belakang bagian bawah selama tugas manual material handling, disebabkan karena kombinasi antara berat beban yang diangkat dan teknik pengangkatan yang digunakan. Beban yang dipegang dan masa tubuh pekerja yang menciptakan otot - otot rangka berada dalam posisi memberikan gaya pada persendian tersebut sebagai upaya untuk meniadakan momen beban tubuh pekerja tersebut.

\section{b. Perancangan Alat Bantu Penganganan Material}

Tahap selanjutnya berdasarkan hasil analisis sebelumnya, maka dilakukan usulan perbaikan sistem kerja melalui perancangan 
alat bantu untuk penanganan material. Rancangan alat bantu ini bertujuan untuk mengurangi besarnya beban yang terjadi pada tulang belakang, sehingga dapat meminimasi terjadinya cidera pada tulang belakang bawah (L5/S1).

\section{c. Analisis Hasil Rancangan}

Pada bagian ini dilakukan analisis terhadap usulan rancangan alat bantu penanganan material agar dapat mengurangi gaya yang dihasilkan. Gaya yang dihasilkan dari pekerjaan mengangkat material dengan menggunakan alat bantu perlu dibandingkan lagi terhadap batasan angkat normal (the action limit) yang direkomendasikan oleh NIOSH Apabila masih memberikan besaran gaya berada diatas batasan yang di rekomendasikan, maka perlu dirancang kembali alat bantu yang dapat meminimasi gaya yang ditimbulkan. The National Institut for Occupational Safety and Health (NIOSH) merekomendasikan dua batasan untuk menghindari resiko cedera pada saat aktivitas pekerjaan manual dalam, yaitu :

\section{- $\quad$ Maximum Permissible Limit (MPL)}

Batasan gaya angkat maksimum yang direkomendasikan adalah berdasarkan Gaya Tekan sebesar 6400 Newton pada $\mathrm{L} 5 / \mathrm{S} 1$.

- Action Limit (AL)

Batasan gaya angkat normal yang direkomendasikan adalah berdasarkan pada Gaya Tekan sebesar 3400 Newton pada L5/S1.

Dengan memperhatikan batasan Gaya Tekan pada L5/S1 maka didapat tiga kriteria untuk menganalisis pekerjaan pengangkatan, yaitu :

- Untuk pekerjaan pengangkatan yang menghasilkan tekanan pada L5/S1 berada diatas Maximum Permissible Limit harus dipandang sebagai pekerjaan yang tidak bisa diterima atau dilakukan secara manual. Tugas pembebanan ini sangat berbahaya untuk kebanyakan pekerja dan diperlukan kontrol teknik agar dilakukan rancangan ulang terhadap sistem kerja tersebut.

- Untuk pekerjaan pengangkatan yang menghasilkan tekanan pada L5/S1 berada diantara Action Limit dan Maximum Permissible Limit tidak bisa diterima tanpa adanya kontrol, pekerjaan tersebut memerlukan pemilihan, penempatan dan pelatihan pegawai untuk melakukan pekerjaan atau dapat dilakukan kembali perbaikan sistem kerja.

- Untuk pekerjaan pengangkatan yang menghasilkan tekanan pada L5/S1 berada dibawah Action Limit dipercaya hanya menimbulkan kemungkinan cedera yang kecil pada kebanyakan pekerja.

\section{PENGUMPULAN DATA DAN PERANCANGAN \\ 3.1. Analisis Cara Pengangkatan Barang Kondisi Awal}

Proses pengangkatan bahan baku kedelai ke atas tungku merupakan pekerjaan utama yang paling sering dilakukan pekerja di pabrik kecap ini. Kedelai yang sudah dibersihkan dan ditempatkan dalam tong dipindahkan ke dekat tungku, lalu tong tersebut diangkat keatas tungku untuk kemudian ditumpahkan ke kuali yang ada di atas tungku. Untuk kondisi saat ini pengangkatan tong dilakukan secara manual oleh pekerja dengan cara memegang pegangan yang ada pada tong sambil membungkukkan badan. Cara pengangkatan secara manual ini sangat beresiko menimbulkan cidera pada pekerja. Selain itu proses pengangkatan yang dilakukan secara terus menerus dalam jangka waktu yang lama dapat menimbulkan cedera otot. Hal ini dapat terjadi karena beban yang diterima oleh setiap segmen tubuh yang berlebihan sehingga dalam jangka waktu yang lama dapat menimbulkan cedera otot. 


\subsection{Perhitungan Gaya Dan Momen Pada Setiap Segmen Tubuh Pada Cara Pengangkatan Secara Manual}

Sebelum melakukan perhitungan gaya pada setiap segmen tubuh terlebih dahulu dilakukan perhitungan gaya awal yaitu merupakan gaya yang dihasilkan sebagai aksi reaksi pada telapak tangan sebagai akibat dari kontak tangan dengan tong. Diagram benda bebas pada saat mengangkat tong dapat dilihat pada gambar 1 .

Perhitungan gaya awal :

$$
\begin{aligned}
& \sum F y=0 \\
& P A y=W \\
& P A \sin \theta_{\text {siku }}=W \\
& P A=W / \sin \theta_{\text {siku. }} \\
& P A=500 / \sin 60^{\circ} \\
& P A=577,35 \mathrm{~N}
\end{aligned}
$$

Selain gaya awal data lain yang diperlukan adalah data posisi tubuh operator dan data dimensi antropometri tubuh. Data ini diperoleh dari pengamatan langsung terhadap posisi dan gerakan - gerakan yang terjadi pada saat mengangkat tong. Data data tersebut digunakan untuk mengidentifikasi dimensi antropometri yang diperlukan dalam perhitungan sudut dan momen pada tiap segmen tubuh. Posisi tubuh dan sudut - sudut yang terbentuk pada saat mengangkat tong dapat dilihat pada gambar 2.

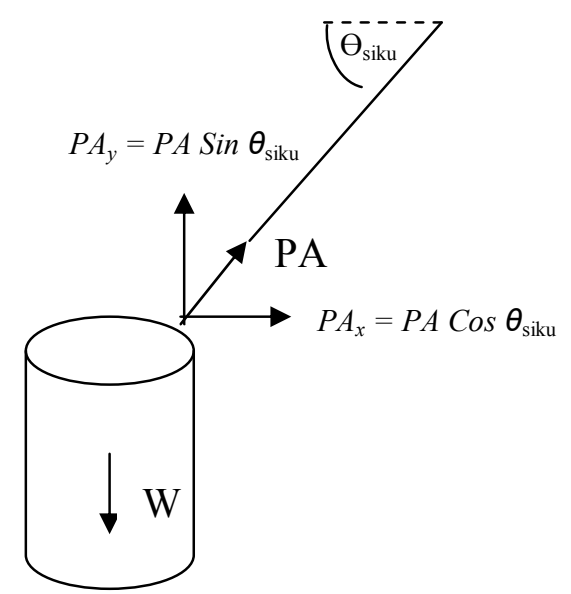

Gambar 1. Diagram Benda Bebas Pada Saat Mengangkat Tong Ke Tungku.
Adapun besarnya berat segmen tubuh, panjang setiap segmen tubuh, dan sudut yang terbentuk diantara segmen tubuh yang berhubungan, dapat dilihat pada lampiran tabel A - B. Gaya yang timbul pada telapak tangan akibat interaksi dengan tong dapat digunakan untuk menghitung gaya yang timbul pada setiap segmen tubuh dengan memanfaatkaan data antropometri setiap segmen tubuh. Contoh perhitungan gaya pada lengan bawah $\left(\mathrm{R}_{1}\right)$ pada saat mengangkat tong ke tungku adalah sebagai berikut :

Panjang lengan bawah : $23 \mathrm{~cm}(0,23 \mathrm{~m})$.

Sudut yang dibentuk pada siku $\theta$ siku : $60^{\circ}$.

Gaya angkat $\mathrm{P}_{\mathrm{A}}=577,35 \mathrm{~N}$.

Berat lengan bawah dan tangan :

$\mathrm{W} 1=10,275 \mathrm{~N}$.

$\mathrm{P} \overline{\mathrm{A}_{\mathrm{x}}}=\mathrm{P}_{\mathrm{A}} \cos \theta$ siku

$$
=577,35 \cos \left(60^{\circ}\right)=288,675 \mathrm{~N}
$$

$\mathrm{P} \overline{\mathrm{A}_{\mathrm{y}}}=\mathrm{P}_{\mathrm{A}} \sin \theta \mathrm{siku}$

$$
=577,35 \sin \left(60^{\circ}\right)=500 \mathrm{~N}
$$

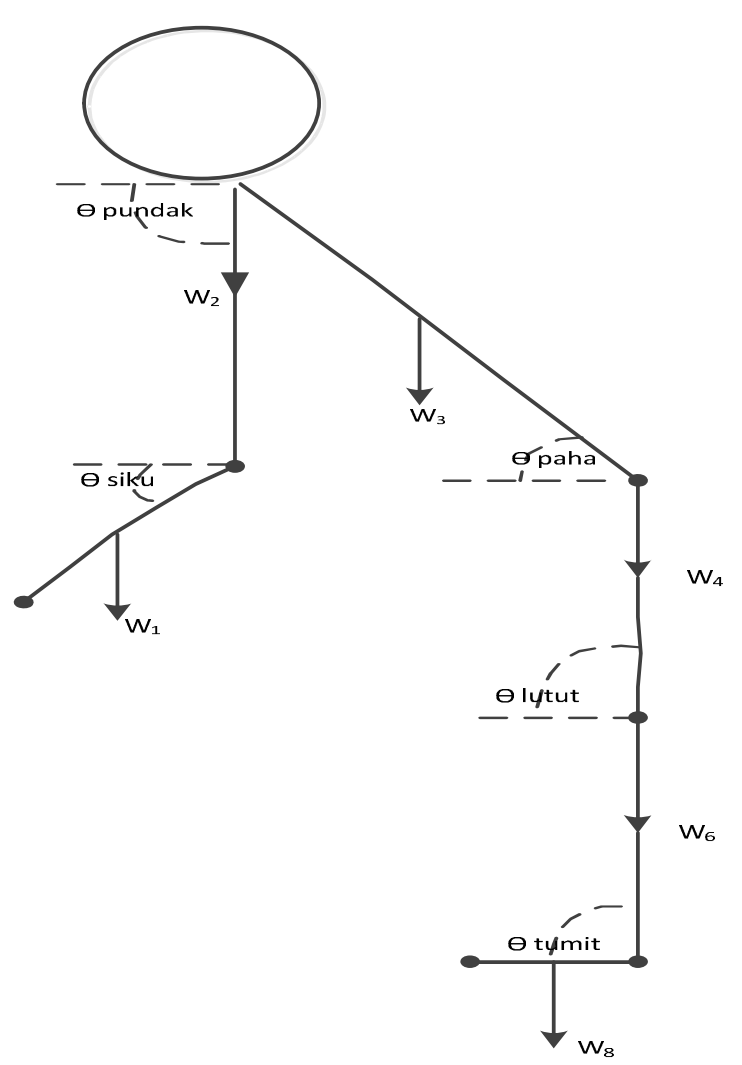

Gambar 2. Posisi Tubuh dan Sudut - sudut yang Terbentuk Pada Tubuh Operator Pada Pengangkatan Secara Manual. 
Tabel 1. Rekapitulasi Perhitungan Gaya dan Momen pada Saat Mengangkat Tong ke Tungku

\begin{tabular}{c|c|c|c|c}
\hline \multirow{2}{*}{ Sambungan Anggota Tubuh } & \multicolumn{2}{|c|}{$\begin{array}{c}\text { Gaya Pada Sambungan } \\
\text { Anggota Tubuh (N) }\end{array}$} & \multicolumn{2}{c}{$\begin{array}{c}\text { Momen Pada } \\
\text { Sambungan Anggota } \\
\text { Tubuh (Nm) }\end{array}$} \\
\hline Siku & $\mathrm{R}_{1}$ & 568,47 & $\mathrm{M}_{1}$ & 0,83 \\
Pundak & $\mathrm{R}_{2}$ & 553,95 & $\mathrm{M}_{2}$ & 75,18 \\
Pinggul & $\mathrm{R}_{3}$ & 875,07 & $\mathrm{M}_{3}$ & 526,73 \\
Lutut Kanan & $\mathrm{R}_{4}$ & 380,94 & $\mathrm{M}_{4}$ & 412,65 \\
Lutut Kiri & $\mathrm{R}_{5}$ & 380,94 & $\mathrm{M}_{5}$ & 412,65 \\
Tumit kanan & $\mathrm{R}_{6}$ & 405,15 & $\mathrm{M}_{6}$ & 477,34 \\
Tumit kiri & $\mathrm{R}_{7}$ & 405,15 & $\mathrm{M}_{7}$ & 477,34 \\
Ujung kaki kanan & $\mathrm{R}_{8}$ & 397,26 & $\mathrm{M}_{8}$ & 564,51 \\
Ujung kaki kiri & $\mathrm{R}_{9}$ & 397,26 & $\mathrm{M}_{9}$ & 564,51 \\
\hline
\end{tabular}

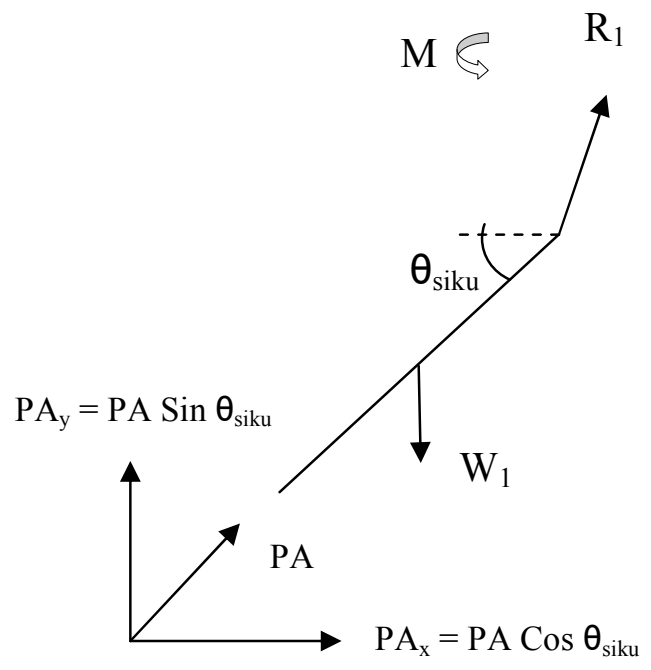

Gambar 3. Diagram Benda Bebas untuk Lengan Bawah Saat Mengangkat Tong ke Tungku.

Maka Gaya pada siku $\mathrm{R}_{1}$ :

$$
\begin{aligned}
\overline{R 1} & =\sqrt{P A x^{2}+(P A y-W 1)^{2}} \ldots \ldots \ldots \ldots . . . \\
\overline{R 1} & =\sqrt{288,675^{2}+(500-10,275)^{2}} \\
& =568,47 \mathrm{~N} .
\end{aligned}
$$

Menghitung Momen pada siku $\mathrm{R}_{1}$ :

$\mathrm{M} 1=\mathrm{jCM} 1 \cos \theta \operatorname{siku} * \mathrm{~W} 1+\mathrm{PA}_{\mathrm{x}} \sin \theta$ siku* ECM tangan $-\underline{\mathrm{PA}_{\mathrm{y}} \cos \theta}$ siku $* \mathrm{ECM}$

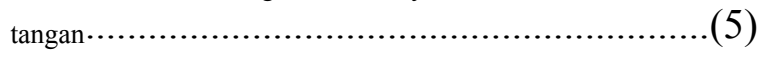

$$
\begin{aligned}
= & 0,161 * \cos \left(60^{0}\right) * 10,275+288,675^{*} \sin \\
& \left(60^{0}\right) * 0,321-500^{*} \cos \left(60^{\circ}\right) * 0,321 \\
= & 0,83 \mathrm{Nm} .
\end{aligned}
$$

Dimana :

jCM1 : Jarak dari siku ke titik pusat massa lengan bawah + telapak tangan

$\overline{\mathrm{ECM}}_{\text {tangan }}$ : Jarak dari siku ke pusat massa telapak tangan

Dengan menggunakan prinsip efek domino maka gaya yang terjadi pada lengan bawah ini akan menimbulkan gaya pada lengan bagian atas, selanjutnya akan menimbulkan gaya pada bahu, lalu pada tulang belakang dan seterusnya sampai ke kaki. Rekapitulasi perhitungan gaya dan momen pada setiap segmen tubuh pekerja dapat dilihat pada tabel 1 . 


\subsection{Perancangan \\ Pengangkatan Barang}

Berdasarkan analisis terhadap cara pengangkatan tong pada kondisi awal, serta dengan memperhatikan keluhan dari pada pegawai yag sering merasakan pegal pada bagian bahu, lengan bagian atas, dan pinggang, maka pada penelitian ini akan diusulkan cara pengangkatan tong dengan memanfaatkan sistem katrol yang ditarik menggunakan tali penarik tong. Adapun gambaran posisi kerja dari usulan cara kerja baru dapat dilihat pada gambar 4 .

\subsection{Perhitungan Gaya dan Momen Pada Setiap Segmen Tubuh Pada Cara Pengangkatan Dengan Alat Bantu}

Besarnya gaya tarik pada tali penarik dengan menggunakan katrol yang ditarik dalam waktu tidak lebih dari 5 menit adalah sebesar $50 \mathrm{~kg}$. Sehingga gaya yang diterima oleh tangan sebesar $40 \mathrm{~kg} * 10 \mathrm{~m} / \mathrm{s}^{2}=400 \mathrm{~N}$. Sedangkan tinggi posisi katrol yaitu $250 \mathrm{~cm}$, hal ini berdasarkan jangkauan ujung lengan pekerja sebesar 171,75 dan memperhitungkan kelonggaran tinggi sebesar $78,25 \mathrm{~cm}$.

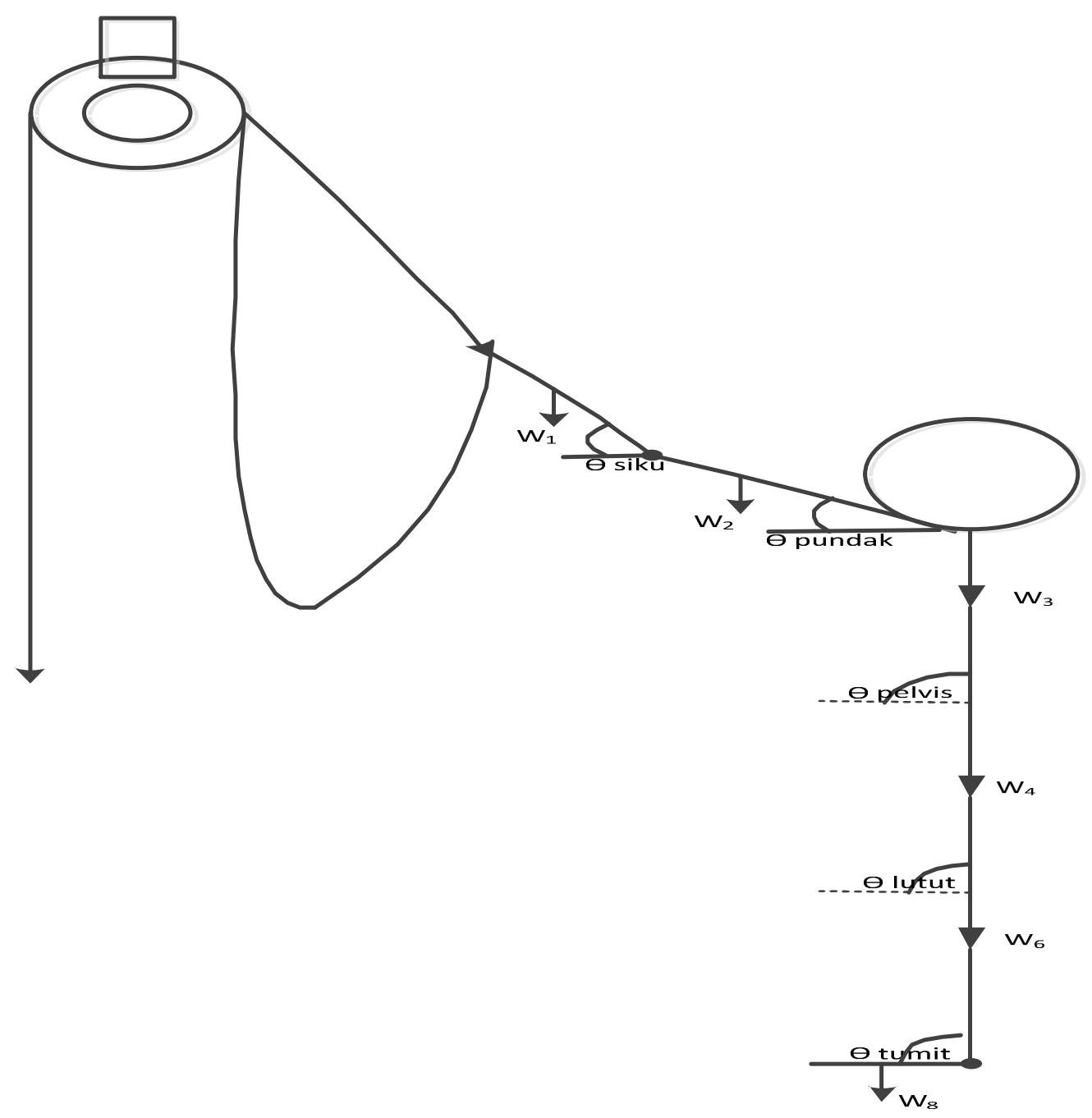

Gambar 4. Posisi dan Sudut yang Terbentuk Pada Usulan Pengangkatan Tong ke Tungku. 
Tabel 2. Rekapitulasi Perhitungan Gaya dan Momen pada Saat Mengangkat Tong ke Tungku Dengan Cara Usulan

\begin{tabular}{c|c|c|c|c}
\hline & \multicolumn{2}{|c|}{$\begin{array}{c}\text { Gaya Pada Sambungan } \\
\text { Anggota Tubuh }(\mathbf{N})\end{array}$} & \multicolumn{2}{c}{$\begin{array}{c}\text { Momen Pada Sambungan } \\
\text { Anggota Tubuh (Nm) }\end{array}$} \\
\hline Siku & $\mathrm{R}_{1}$ & 409,67 & $\mathrm{M}_{1}$ & 0,56 \\
Pundak & $\mathrm{R}_{2}$ & 393,74 & $\mathrm{M}_{2}$ & 18,31 \\
Pinggul & $\mathrm{R}_{3}$ & 735,37 & $\mathrm{M}_{3}$ & $-97,28$ \\
Lutut Kanan & $\mathrm{R}_{4}$ & 308,44 & $\mathrm{M}_{4}$ & $-43,25$ \\
Lutut Kiri & $\mathrm{R}_{5}$ & 308,44 & $\mathrm{M}_{5}$ & $-43,25$ \\
Tumit kanan & $\mathrm{R}_{6}$ & 283,12 & $\mathrm{M}_{6}$ & $-73,85$ \\
Tumit kiri & $\mathrm{R}_{7}$ & 283,12 & $\mathrm{M}_{7}$ & $-73,85$ \\
Ujung kaki kanan & $\mathrm{R}_{8}$ & 291,33 & $\mathrm{M}_{8}$ & $-10,82$ \\
Ujung kaki kiri & $\mathrm{R}_{9}$ & 291,33 & $\mathrm{M}_{9}$ & $-10,82$ \\
\hline
\end{tabular}

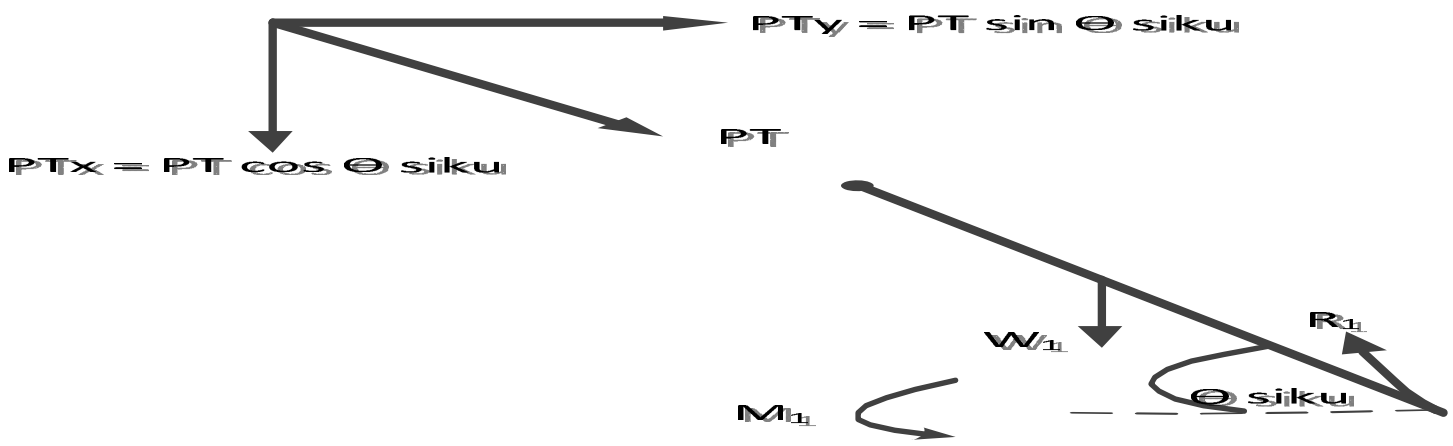

Gambar 4 Diagram Benda Bebas untuk Lengan Bawah Saat Mengangkat Tong ke Tungku Dengan Cara Usulan.

Contoh perhitungan gaya pada saat menggunakan katrol adalah sebagai berikut :

Panjang lengan bawah : $23 \mathrm{~cm}(0,23 \mathrm{~m})$.

Sudut yang dibentuk pada siku $\theta$ siku : $70^{\circ}$.

Gaya angkat $\mathrm{P}_{\mathrm{T}}=400 \mathrm{~N}$.

Berat lengan bawah dan tangan : $\mathrm{W} 1=$ $10,275 \mathrm{~N}$.

$$
\begin{aligned}
& \overline{\mathrm{PT}}_{\mathrm{x}}=\mathrm{P}_{\mathrm{T}} \cos \theta \text { siku } \\
& =400 \cos \left(70^{\circ}\right)=136,808 \mathrm{~N} \text {. } \\
& \mathrm{PT}_{\mathrm{y}}=\mathrm{P}_{\mathrm{T}} \sin \theta \text { siku. } \\
& =400 \sin \left(70^{\circ}\right)=375,877 \mathrm{~N} \text {. }
\end{aligned}
$$

Maka Gaya pada siku; $\mathrm{R}_{1}$ :

$$
\begin{aligned}
& \overline{R 1}=\sqrt{P T x^{2}+(P T y-W 1)^{2}} \\
& \overline{R 1}=\sqrt{136,808^{2}+(375,877+10,275)^{2}} \\
& =409,670 \mathrm{~N} \text {. }
\end{aligned}
$$

Menghitung Momen pada siku $\mathrm{R}_{1}$ :

$\mathrm{M} 1=\mathrm{jCM} 1 \cos \theta$ siku $* \mathrm{~W} 1-\mathrm{PT}_{\mathrm{x}} \sin \theta$ siku* ECM tangan $+\overline{\mathrm{PT}}_{\mathrm{y}} \cos \theta$ siku $* \mathrm{ECM}$
$=0,159 * \cos \left(70^{0}\right) * 10,275-136,808 * \sin$ $\left(70^{0}\right) * 0,319+375,877^{*} \cos \left(70^{0}\right)^{*} 0,319$ $=0,560 \mathrm{Nm}$.

Dimana :

jCM1 : Jarak dari siku ke titik pusat massa lengan bawah + telapak tangan

$\overline{\mathrm{ECM}}_{\text {tangan }}$ : Jarak dari siku ke pusat massa lengan bawah.

Seperti yang sudah dilaukan sebelumnya, maka dengan diperolehnya besarnya gaya dan momen pada siku, maka dengan memanfaatkan efek domino dapat dihitung besarnya gaya dan momen pada setiap segmen tubuh pekerja pada saat melakukan pengangangkatan tong dengan posisi usulan. Adapun hasil perhitungan gaya dan momen untuk setiap segmen tubuh dapat dilihat pada tabel 2 . 
Tabel 3. Perbandingan Gaya Pada Cara Lama dan Cara Baru

\begin{tabular}{c|l|c|c|c}
\hline \multirow{2}{*}{ Sambungan Anggota Tubuh } & \multicolumn{3}{|c}{ Gaya Pada Sambungan Anggota Tubuh (N) } \\
\cline { 2 - 5 } & \multicolumn{2}{|c|}{ Cara Lama } & \multicolumn{2}{c}{ Cara Usulan } \\
\hline Siku & $\mathrm{R}_{1}$ & 568,47 & $\mathrm{R}_{1}$ & 409,67 \\
Pundak & $\mathrm{R}_{2}$ & 553,95 & $\mathrm{R}_{2}$ & 393,74 \\
Pinggul & $\mathrm{R}_{3}$ & 875,07 & $\mathrm{R}_{3}$ & 735,37 \\
Lutut Kanan & $\mathrm{R}_{4}$ & 380,94 & $\mathrm{R}_{4}$ & 308,44 \\
Lutut Kiri & $\mathrm{R}_{5}$ & 380,94 & $\mathrm{R}_{5}$ & 308,44 \\
Tumit kanan & $\mathrm{R}_{6}$ & 405,15 & $\mathrm{R}_{6}$ & 283,12 \\
Tumit kiri & $\mathrm{R}_{7}$ & 405,15 & $\mathrm{R}_{7}$ & 283,12 \\
Ujung kaki kanan & $\mathrm{R}_{8}$ & 397,26 & $\mathrm{R}_{8}$ & 291,33 \\
Ujung kaki kiri & $\mathrm{R}_{9}$ & 397,26 & $\mathrm{R}_{9}$ & 91,33 \\
\hline
\end{tabular}

Tabel 4. Perbandingan Gaya Pada Cara Lama dan Cara Baru

\begin{tabular}{c|c|c|c|c}
\hline \multirow{2}{*}{ Sambungan Anggota Tubuh } & \multicolumn{2}{|c}{ Momen Pada Sambungan Anggota Tubuh (Nm) } \\
\cline { 2 - 5 } & \multicolumn{2}{|c}{ Cara Lama } & \multicolumn{2}{c}{ Cara Usulan } \\
\hline Siku & $\mathrm{M}_{1}$ & 0,83 & $\mathrm{M}_{1}$ & 0,56 \\
Pundak & $\mathrm{M}_{2}$ & 75,18 & $\mathrm{M}_{2}$ & 18,31 \\
Pinggul & $\mathrm{M}_{3}$ & 526,73 & $\mathrm{M}_{3}$ & $-97,28$ \\
Lutut Kanan & $\mathrm{M}_{4}$ & 412,65 & $\mathrm{M}_{4}$ & $-43,25$ \\
Lutut Kiri & $\mathrm{M}_{5}$ & 412,65 & $\mathrm{M}_{5}$ & $-43,25$ \\
Tumit kanan & $\mathrm{M}_{6}$ & 477,34 & $\mathrm{M}_{6}$ & $-73,85$ \\
Tumit kiri & $\mathrm{M}_{7}$ & 477,34 & $\mathrm{M}_{7}$ & $-73,85$ \\
Ujung kaki kanan & $\mathrm{M}_{8}$ & 564,51 & $\mathrm{M}_{8}$ & $-10,82$ \\
Ujung kaki kiri & $\mathrm{M}_{9}$ & 564,51 & $\mathrm{M}_{9}$ & $-10,82$ \\
\hline
\end{tabular}

\section{ANALISIS HASIL RANCANGAN}

Berdasarkan hasil pembahasan pada bagian sebelumnya maka dapat dilakukan analisis terhadap perbaikan cara kerja pengangkatan dan pemindahan tong oleh pekerja. Dari hasil perhitungan gaya pada pengangkatan cara lama diperoleh besarnya gaya yang rata-rata berada dibawah $3400 \mathrm{~N}$, yaitu batasan maksimum gaya yang direkomendasikan pada proses pengangkatan. Hal ini menunjukkan bahwa gaya beban kerja tersebut masih dapat dikategorikan pekerjaan ringan, namun sehubungan dengan pekerjaan tersebut dilakukan berulang-ulang sehingga secara akumulasi dapat menimbulkan cedera otot.
Dengan dilakukan perbaikan terhadap cara pengangkatan dan pemindahan tong, yaitu dengan bantuan rancangan sistem katrol, maka diperoleh besarnya gaya pada persendian anggota tubuh yang lebih kecil dari pada gaya dengan cara lama. Hal ini menunjukkan bahwa cara kerja baru akan memberikan beban kerja yang lebih kecil sehingga secara akumulasi diharapkan dapat meminimasi. Adapun perbandingan besarnya gaya dan momen pada setiap segmen tubuh untuk kondisi awal dan kondisi usulan perbaikan kerja dapat dilihat pada tabel 3-4. 


\section{KESIMPULAN}

Kesimpulan dari penelitian yang telah dilakukan adalah :

1. Proses pengangkatan secara manual yang dilakukan dengan cara lama sangat beresiko menimbulkan cedera otot pada pekerjanya. Meskipun gaya yang dihasilkan massih dibawah batas yang dijinkan, namun karena dilakukan secara berulang-ulang dan terus menerus, maka dapat menimbulkan cedera otot pada pekerja. Pembebanan yang timbul pada segmen tubuh pekerja tidak merata, terutama untuk segmen bagian bahu dan pinggul. Pembebanan yang terpusat pada satu titik ini dapat menimbulkan resiko cedera yang besar.

2. Perlu perbaikan cara kerja dengan dilakukan perancangan alat bantu pengangkatan (material handling), dimana perancangan alat bantu ini tidak bertumpu pada satu titik tetapi merata pada otot telapak tangan dan otot telapak kaki.

3. Pada elemen kerja pengangkatan tong ke tungku untuk alat handling yang baru memiliki gaya yang lebih kecil dari pada dengan cara lama, hal ini menunjukkan bahwa momen yang ditimbulkan juga lebih kecil yang berdampak pada semakin kecilnya beban pada segmen tubuh pekerja. Dengan demikian resiko terjadinya cedera dapat diminimasi.

\section{DAFTAR PUSTAKA}

Chaffin, Don B, and Gunnar B.J. Anderson, 1991. Occupational Biomechanics, $2^{\text {nd }}$ edition, Jhon Willey \& Sons.Inc, New York.

Grandjean, Etienne, 1988. Fitting The Task To The Man, $4^{\text {th }}$ Edition, Taylor \& Francis Ltd, London.

Helianty Yanti, Mona Citra P, Caecilia Sw, 2012. Rancangan Alat Bantu Untuk Meminimasi Gaya Tekan ( $\left.F_{\text {comp }}\right)$ Pada Lempeng Tulang Belakang Bagian Bawah (L5/S1), Jurnal Rekayasa, Itenas Bandung.

Mas'idah Eli, Fatmawati Wiwiek, Ajibta Lazib, 2009. Analisa Manual Material Handling (MMH) dengan menggunakan Metoda Biomekanika untuk Mengidentifikasi Resiko Cidera Tulang Belakang, Jurnal Sultan Agung Vol. XLV No. 119 September- Nopember.

National Institut for OCCUPATIONAL Safety and Health, 1981. Work Practices Guide for Manual Lifting, Dept. of Health and Human Services (NIOSH), Cincinnati, Ohio. 


\section{Lampiran}

Tabel A. Berat dan Panjang Segmen Tubuh Pekerja

\begin{tabular}{|c|c|c|c|c|c|c|}
\hline \multirow[t]{2}{*}{ No } & \multirow[t]{2}{*}{ Joint } & \multirow[t]{2}{*}{ Segmen Tubuh (L) } & \multicolumn{2}{|c|}{ Berat (WL) } & \multicolumn{2}{|c|}{$\begin{array}{c}\text { Panjang Segmen } \\
\text { Tubuh }(\mathbf{j} ; \mathbf{j}-\mathbf{l}) \\
(\mathrm{m})\end{array}$} \\
\hline & & & Lambang & $\mathbf{W L}$ & Lambang & $\mathbf{J} ; \mathbf{j}-\mathbf{I}$ \\
\hline 1 & Siku & Tangan-Lengan Bawah & $\mathrm{W}_{1}$ & 10,275 & $\mathrm{j}_{2} \mathrm{j}_{1}$ & 0,230 \\
\hline 2 & Pundak & Lengan Atas & $\mathrm{W}_{2}$ & 16,939 & $\mathrm{j}_{3} \mathrm{j}_{2}$ & 0,258 \\
\hline 3 & Pinggul & $\begin{array}{l}\text { Kepala-Leher-Badan } \\
\text { Atas }\end{array}$ & $\mathrm{W}_{3}$ & 353,32 & $\mathrm{j}_{4} \mathrm{j}_{3}$ & 0,845 \\
\hline 4 & Lutut Kanan & Paha Kanan & $\mathrm{W}_{4}$ & 60,505 & $\mathrm{j}_{5} \mathrm{j}_{4}$ & 0,395 \\
\hline 5 & Lutut Kiri & Paha Kiri & $\mathrm{W}_{5}$ & 60,505 & $\mathrm{j}_{7} \mathrm{j}_{5}$ & 0,395 \\
\hline 6 & Ujung Kaki Kanan & Kaki Kanan & $\mathrm{W}_{6}$ & 26,026 & $\mathrm{j}_{6} \mathrm{j}_{5}$ & 0,448 \\
\hline 7 & Ujung Kaki Kiri & Kaki Kiri & $\mathrm{W}_{7}$ & 26,026 & $\mathrm{j}_{8} \mathrm{j}_{7}$ & 0,448 \\
\hline 8 & Tumit Kanan & Tungkai Kanan & $\mathrm{W}_{8}$ & 8,454 & $\mathrm{j}_{6} \mathrm{j}_{6}$ & 0,233 \\
\hline 9 & Tumit Kiri & Tungkai Kiri & $\mathrm{W}_{9}$ & 8,454 & $\mathrm{j}_{8} \mathrm{j}_{8}$ & 0,233 \\
\hline
\end{tabular}

Tabel B. Data Ukuran Sudut pada Saat Mengangkat Tong ke Tungku

\begin{tabular}{|c|c|c|c|}
\hline No & Posisi / Dimensi & Lambang & $\begin{array}{c}\text { Sudut } \\
\text { yang } \\
\text { terbentuk } \\
\left.\text { ( }{ }^{0}\right)\end{array}$ \\
\hline 1 & Antara lengan atas dengan jarak horisontal dari bahu & $\Theta$ pundak & 90 \\
\hline 2 & Antara lengan bawah dengan jarak horisontal dari siku & $\Theta$ siku & 60 \\
\hline 3 & Antara badan dengan jarak horisontal dari pinggul & $\Theta$ peivis & 50 \\
\hline 4 & Antara paha kanan dengan jarak horisontal dari lutut kanan & $\Theta$ lutut kanan & 90 \\
\hline 5 & Antara paha kiri dengan jarak horisontal dari lutut kiri & $\Theta$ lutut kiri & 90 \\
\hline 6 & Antara kaki bagian bawah kanan dengan telapak kaki kanan & $\Theta$ tumit kanan & 90 \\
\hline 7 & Antara kaki bagian kiri dengan telapak kaki kiri & $\Theta$ tumit kiri & 90 \\
\hline
\end{tabular}

Tabel C. Data Ukuran Sudut pada Saat Mengangkat Tong ke Tungku pada Usulan Rancangan

\begin{tabular}{|c|c|c|c|}
\hline No & Posisi / Dimensi & Lambang & $\begin{array}{c}\text { Sudut } \\
\text { yang } \\
\text { terbentuk } \\
\left(^{0}\right)\end{array}$ \\
\hline 1 & Antara lengan atas dengan jarak horisontal dari bahu & $\Theta$ pundak & 80 \\
\hline 2 & Antara lengan bawah dengan jarak horisontal dari siku & $\Theta$ siku & 70 \\
\hline 3 & Antara badan dengan jarak horisontal dari pinggul & $\Theta$ peivis & 90 \\
\hline 4 & Antara paha kanan dengan jarak horisontal dari lutut kanan & $\Theta$ lutut kanan & 90 \\
\hline 5 & Antara paha kiri dengan jarak horisontal dari lutut kiri & $\Theta$ lutut kiri & 90 \\
\hline 6 & Antara kaki bagian bawah kanan dengan telapak kaki kanan & $\Theta$ tumit kanan & 90 \\
\hline 7 & Antara kaki bagian kiri dengan telapak kaki kiri & $\Theta$ tumit kiri & 90 \\
\hline
\end{tabular}

